\title{
Cerebral toxoplasmosis in a patient with acquired immunodeficiency syndrome
}

\author{
Toxoplasmose cerebral em paciente com a \\ síndrome da imunodeficiência adquirida
}

José Roberto Lambertucci ${ }^{1}$, Luciana Cristina dos Santos Silva ${ }^{1}$ and Leonardo Campos de Queiroz ${ }^{2}$

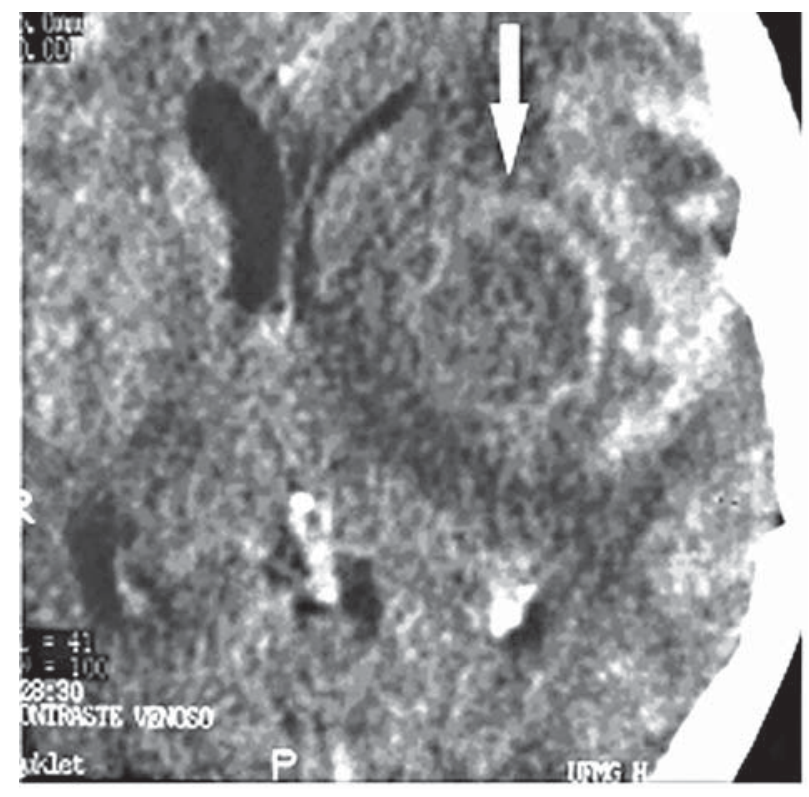

A

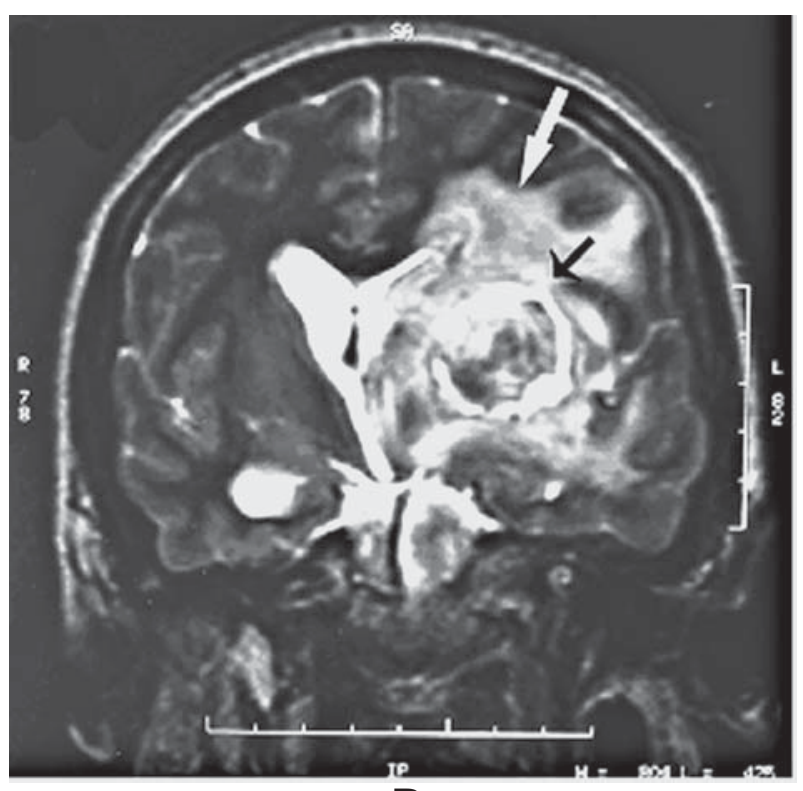

B

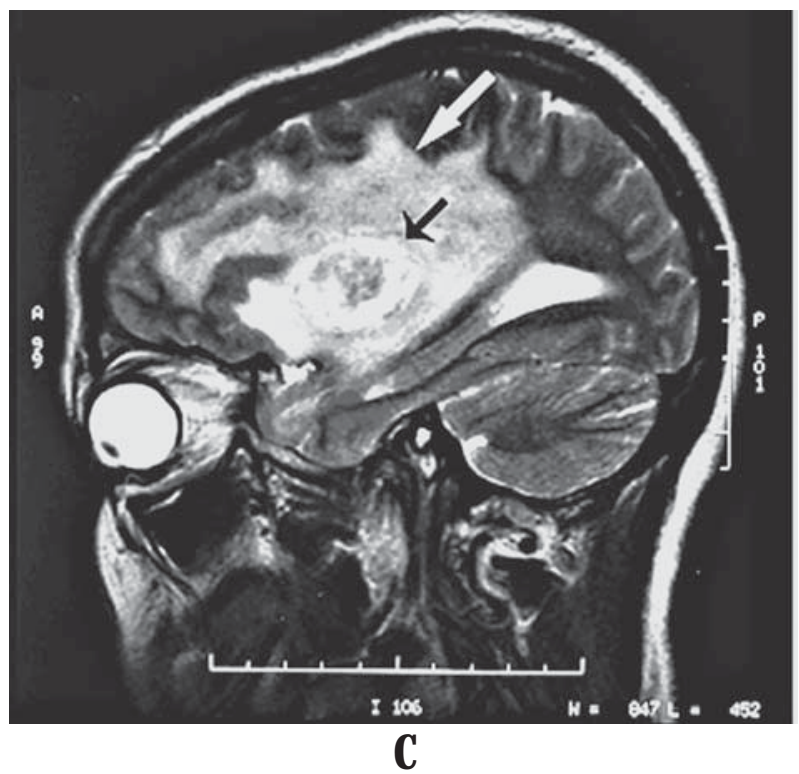

1. Departamento de Clínica Médica do Serviço de Doenças Infecciosas e Parasitárias da Universidade Federal de Minas Gerais, Belo Horizonte, MG. 2. Departamento de Radiologia da Faculdade de Medicina da Universidade Federal de Minas Gerais, Belo Horizonte, MG.

Address to: Prof. José Roberto Lambertucci. Av. Alfredo Balena 190, 30130-100 Belo Horizonte, MG, Brasil.

e-mail: lamber@uai.com.br

Recebido para publicação em 2/8/2006

Aceito em 8/9/2006 
A 45-year-old woman was admitted to hospital with a history of right hemiparesis followed by mental confusion, delirium and seizures that started 2 days prior to admission. She had tested HIV positive in a routine check up performed seven years before, but had rejected the diagnosis and refused counseling and treatment. A CT scan of the brain showed a cerebral lesion with mass effect and compression of the lateral ventricle; after contrast injection, enhancement of the lesion was achieved, revealing a ring appearance ( Figure A; arrow) . Magnetic resonance imaging confirmed the lesion (Figures 2 and 3; black arrows) and showed a large area of edema around the main tumor (Figures 2 and 3; white arrows). A diagnosis of cerebral toxoplasmosis was assayed and treatment was initiated with sulfadiazine, pyrimethamine and folinic acid. Phenytoin was also given for seizure control. She improved rapidly and 50 days after being discharged from the hospital she was feeling well.

A paciente, de 45 anos, foi admitida ao hospital com história de hemiparesia direita seguida de confusão mental, delírio e convulsões, de início havia dois dias. Durante exames rotineiros, a paciente foi informada de que 0 teste para 0 HIV no soro resultara positivo. Entretanto, ela negou a possibilidade de estar infectada e recusou aconselhamento e tratamento. Uma tomografia computadorizada do crânio mostrou lesão cerebral expansiva, com efeito de massa e compressão do ventrículo lateral; após injeção de contraste intravenoso definiu-se melhor a lesão tumoral e houve captação do contraste em anel (Figura A - seta). Aressonância magnética confirmou a presença da massa tumoral (Figuras B e C; seta preta) e mostrou extensa área de edema em torno da lesão (Figuras B e C; setas brancas). 0 diagnóstico de toxoplasmose cerebral se impôs; iniciou-se, a seguir, o tratamento com sulfadiazina, pirimetamina e ácido folínico. Ela também recebeu difenil-hidantoína para tratamento das convulsões. Houve melhora rápida e progressiva. No controle de 50 dias, após a alta hospitalar, a paciente sentia-se bem.

\section{REFERENCES}

1. Borges AS, Figueiredo JFC. Detection of anti-Toxoplasma gondii IgG, IgM and IgA immunoglobulins in the serum, cerebrospinal fluid and saliva of patients with acquired immunodeficiency syndrome and neurotoxoplasmosis. Arquivos de Neuropsiquiatria 4: 1033-1037, 2004.

2. Nobre V, Braga E, Rayes A, Serufo JC, Godoy P, Numes N, Antunes CM, Lambertucci JR. Opportunistic infections in patients with Aids admitted to an University Hospital of the Southeast of Brazil. Revista do Instituto de Medicina Tropical de São Paulo 45: 69-74, 2003.

3. Silva LA, Vieira RS, Serafini LN, Carlotti CG, Figueiredo JFC. Toxoplasmosis of the central nervous system in a patient without immunosuppression. Revista da Sociedade Brasileira de Medicina Tropical 34: 487-490, 2001. 